\title{
Determinants of Compliance With The Implementation of The Covid-19 Health Protocol In The Community of Kediri City
}

\author{
Dhita Kurnia Sari*, Alfian Fawzi \\ Institute of Health Sciences STRADA Indonesia, Kediri, Indonesia \\ Corresponding author:deeniasari88@gmail.com
}

\begin{abstract}
Background: The implementation of the Covid-19 disease prevention health protocol is still a problem in some areas. Many police officers found violations of the Covid-19 prevention health protocol. There are indications that the behavior of the Indonesian people is not ready to face the covid-19 outbreak, which is characterized by four types of behavior, one of which shows non-compliance.

Purpose: This study aimed to examine what are the most dominant determinants of knowledge, anxiety, age, gender, and personality type in influencing compliance in implementing the COVID-19 health protocol.

Methods: The population in this study is the entire community in the city of Kediri. By using accidental sampling method with a cross-sectional approach. And the sample obtained as many as 114 respondents.

Results: The results of the research that have been carried out and analyzed show that the variables of knowledge, personality and anxiety affect health protocol compliance by $57.4 \%$ and the rest are influenced by other variables that have not been studied, and the most influencing variable in the study is the knowledge variable in the partial test.

Conclusion: Compliance and awareness in the implementation of the covid 19 protocol, there is a need for cooperation from the government to the community so that the spread of covid 19 in Indonesia can be prevented.
\end{abstract}

Keywords: Covid-19, Health Protocol Compliance, Personality, Anxiety, Knowledge. 
Journal Of Nursing Practice

http://thejnp.org

ISSN: 2614-3488 (print); 2614-3496 (online)

Vol.5 No.1. October 2021. Page.189-195

\section{BACKGROUND}

The implementation of the Covid-19 prevention protocol in Indonesia is still a problem in terms of enforcing discipline. Anticipating an increase in the spread and number of infections, the public is encouraged to adopt a new healthy lifestyle according to health protocols during the Corona virus pandemic. One form of the protocol is to maintain cleanliness and not to make direct contact with positive Corona virus patients (Izzaty, 2020). Then, use a protective face mask when traveling or outside the home (Howard et al., 2020). Next, maintain cleanliness by washing hands or using hand sanitizer (Lee et al., 2020). The last is the application of social distancing by keeping a distance of 1 meter and covering your mouth when coughing or sneezing using your arms (Hafeez et al., 2020).

According to data reported by the World Health Organization (WHO) as of September $20^{\text {th }}, 2020$. Globally, as of 11:46 CEST, 20 September 2020, there were 30,624,590 confirmed cases of COVID-19, including 953,903 deaths, reported to WHO. Covid-19 cases in Indonesia as of September 19, 2020, namely: 107,863 people still being monitored, Confirmation (9,448 deaths and 3.9\% CFR), 1,457,515 negative cases, 1,698,202 specimens examined.

The basic nature and human need to socialize intensively are limited by the physical distancing policy. This policy triggers non-compliance behavior as in news media reports, some students in Yogyakarta hanging out at internet cafes (Pratomo, 2020). Security guards were tight to sterilize crowded areas such as the dispersal of residents in South Sulawesi who were hanging out past curfew in the square by the local police (Tuwu. D, 2020) and the dispersal of dozens of residents in Gladak Serang, Probolinggo before spraying disinfectant.

The results of Huang \& Zhao, (2020) research show that knowledge of the benefits of using masks affects protective behavior (using masks) in influenza pandemic situations. During a pandemic situation, the desire for isolation is determined by attitudes, perceptions of social norms and perceptions of behavioral control (Zhang, et al, 2020). Research by Wise, et al (2020) shows that the perception of the risk of contracting and the perception of the impact of COVID-19 (economy, health services) increases individual protective behavior (washing hands, maintaining social distance). Fear and anxiety about the COVID19 virus play an important role in influencing protective behaviors, such as hand washing, social distancing (Harper et al., 2020).

Age and social status do not predict healthy behavior (washing hands, wearing masks) (Huang \& Zhao: 2010; Wise et al. (2020), while Zhang et al. (2020) study showed that the desire for self-isolation during the COVID-19 pandemic was determined by education, status (married or unmarried) and socioeconomic status. Individuals who have higher education, are married and of high socioeconomic status tend to have a desire to self-isolate during the COVID-19 pandemic. This can be due to their concern, knowledge and perception of risk. COVID-19 is higher, so the desire for isolation is higher.

The use of masks is very much determined by the immediate environment (family) and surroundings. For example, individuals do not use masks because they see that many people still don't use masks, meaning that community norms or habits affect individuals in their behavior. In addition, the use of media is important to spread social values or norms, so that people are more obedient to government advice. The media used also vary, ranging from print media, mass media, accompanied by online media that use competent and influential people for social influence on people's behavior.

Personality is also related to conformity (the way we adapt to the social environment). The results of the study show that people with neurotic personality types (easily anxious, emotionally unstable) are more susceptible to social influences (Kiemute, \& Julita, 2019; Van Berkel, et al., 2020). People who are easily worried about COVID-19 tend to be more 


\section{Journal Of Nursing Practice}

http://thejnp.org

ISSN: 2614-3488 (print); 2614-3496 (online)

Vol.5 No.1. October 2021. Page.189-195

obedient to government advice, such as wearing masks, keeping distance and washing hands (health protocols).

From a review of some of the literature, it is important for us to examine what are the most dominant determinants of knowledge, anxiety, age, gender, and personality type in influencing compliance in implementing the COVID-19 health protocol.

\section{METHODS}

\section{Design}

This study is a quantitative observational analytic study with a cross-sectional research design because the data supporting the research variables were collected at the same time.

\section{Participants}

The population in this study is the entire community in the city of Kediri with the age of 20-55 years. The sampling technique used in this study was accidental sampling, by spreading the google form to the entire community of Kediri City through health cadres in each working area of the entire Kediri City Health Center. The sample obtained was 114 respondents from the work area of 9 Kediri City Health Centers.

\section{Data Collection Tools}

Introductory Information Form: In this form, information such as the age of the patient, educational status, and profession from the respondents.

Depression, Anxiety and Stress Scale: The measuring instrument is used to determine the level of anxiety, stress and depression that a person experiences. the instrument consists of 42 differentiated questions to measure the 3 categories. Assessment is given using the normal category, mild anxiety, moderate anxiety, severe/severe anxiety and very severe anxiety (panic).

Knowledge Quessionare: The knowledge variable is measured and ordinally categorized. The knowledge of the people of Kediri City is categorized into three level, namely High (if the respondent's score is $(76-100)$, Enough $(56-75)$ and Less (if $<56)$.

Personality Type Questionnaire: Personality type was measured using a questionnaire from Raehanul Bahrain (2019). There are 4 categories of personality types, namely sanguine, melancholic, chorelic and phlegmatic.

\section{Data Collection Procedure}

The data collection process in this study was carried out online. Data was collected using a google form which was distributed to all residents of the city of Kediri through health cadres in the working area of 9 Kediri City Health Centers.

\section{Data analysis}

SPSS (Statistical Package for Social Science) 25 package program was used for the coding of the data obtained from the study and for the statistical analysis of the data, and it was studied with a $95 \%$ confidence level. This study uses logistic regression statistical tests by looking at the relationship of each variable and seeing how close the relationship is between the variables X1 (knowledge), X2 (personality type), X3 (anxiety) and Y (compliance).

\section{Ethical consideration}

Approval was obtained from IIK STRADA Research Ethics Committee for the study with the number 2614/KEPK/IX/2021, dated 01.09.2021. In order to ensure the protection of individual rights in the research, the ethical principle was followed with the "Voluntary Information and Approval Form". In addition, it was said that individual information would be protected after sharing with the researcher, and care was taken to comply with the ethical principles of "Autonomy" and "Protection of Confidentiality". 


\section{Journal Of Nursing Practice}

http://thejnp.org

ISSN: 2614-3488 (print); 2614-3496 (online)

Vol.5 No.1. October 2021. Page.189-195

\section{RESULTS}

Univariate analysis

Table 1. frequency of respondent's age

\begin{tabular}{lcc}
\hline Age & Frequency & Percentage \\
\hline $20-25$ Year & 21 & $18 \%$ \\
$26-30$ Year & 15 & $13 \%$ \\
$31-35$ Year & 46 & $40 \%$ \\
$36-40$ Year & 4 & $4 \%$ \\
$41-45$ Year & 6 & $5 \%$ \\
$46-50$ Year & 18 & $16 \%$ \\
$51-55$ Year & 4 & $4 \%$ \\
\hline
\end{tabular}

Table 1 data obtained from a total of 114 respondents, most of the respondents aged 31-35 $(40 \%)$

Table 2. respondent's education frequency

\begin{tabular}{lcc}
\hline Education & Frequency & Percentage \\
\hline Elementary School & 6 & $5 \%$ \\
Junior High School & 17 & $15 \%$ \\
Senior High School & 46 & $40 \%$ \\
Diploma & 11 & $10 \%$ \\
Bachelor & 28 & $25 \%$ \\
Postgraduate & 6 & $5 \%$ \\
\hline
\end{tabular}

Data table. 2 is obtained from a total of 114 respondents, most of them have high school education $(40 \%)$

Table 3. frequency of respondent's knowledge

\begin{tabular}{lcc}
\hline Knowledge & Total & Percentage \\
\hline Good & 42 & $37 \%$ \\
Enough & 55 & $48 \%$ \\
Bad & 17 & $15 \%$ \\
\hline
\end{tabular}

Table.3 data obtained from a total of 114 respondents, most of the respondents were knowledgeable in the sufficient category (48\%)

Tabel 4. Frequency of respondent's personality

\begin{tabular}{lcc}
\hline Personality & Total & Percentage \\
\hline Plegmatis & 32 & $28 \%$ \\
Melankolis & 53 & $46 \%$ \\
Koleris & 19 & $17 \%$ \\
Sanguinis & 10 & $9 \%$ \\
\hline
\end{tabular}

Table 4 data obtained from a total of 114 respondents, most of the respondents have a melancholic personality tendency (46\%).

Table 5. anxiety frequency

\begin{tabular}{lcc}
\hline Anxiety & Total & Percentage \\
\hline Normal & 18 & $16 \%$ \\
Mild & 8 & $7 \%$
\end{tabular}


Journal Of Nursing Practice

http://thejnp.org

ISSN: 2614-3488 (print); 2614-3496 (online)

Vol.5 No.1. October 2021. Page.189-195

Moderate

60

$53 \%$

Severe

28

$25 \%$

Awfully

0

$0 \%$

Table 5 data obtained from a total of 114 respondents, most of the respondents had anxiety in the moderate category (53\%).

Table 6. compliance frequency

\begin{tabular}{lcc}
\hline Compliance & Total & Percentage \\
\hline Obey & 93 & $82 \%$ \\
Not Obey & 21 & $18 \%$ \\
\hline
\end{tabular}

Table 6 data obtained from a total of 114 respondents, most of the respondents have compliance in the obedient category of $(82 \%)$.

Analisis Multivariate (ordinal regression)

\begin{tabular}{lrrr}
\hline & -2 Log & \multicolumn{2}{c}{ Cox \& Snell R Nagelkerke R } \\
Step & likelihood & Square & Square \\
\hline 1 & $57.058^{\text {a }}$ & .349 & .574 \\
\hline
\end{tabular}

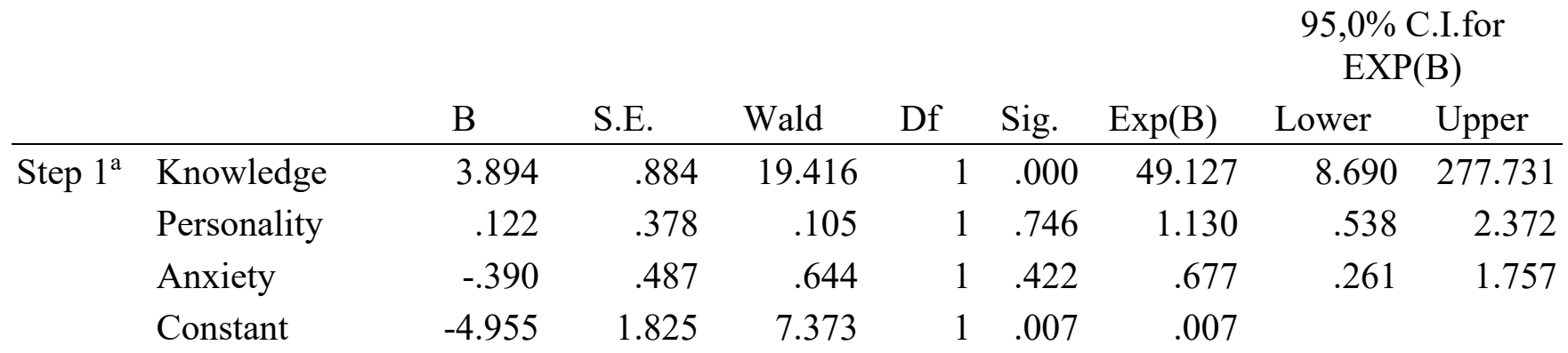

a. Variable(s) entered on step 1: Knowledge, Personality, Anxiety.

The data in the logistic regression test results table shows that the omnibus test model value shows a $\mathrm{p}$ value $(0.000)$ which means the regression model is appropriate and shows that the knowledge, personality and anxiety variables have an impact/affect the covid health protocol compliance variable $=19$ together, the magnitude of the effect of the variable The independent variable on the dependent variable is indicated by the value of $r(0.574)$, which means that the independent variable has an influence on the dependent variable by $57.4 \%$ and the rest is influenced by other variables.

\section{DISCUSSION}

The results of the study obtained a total sample of 114 respondents, the results of the variable knowledge of respondents about covid 19 showed (48\%) in the sufficient category to have a history of education mostly at the high school level (40\%), with an average age of 31-35 years of (40\%). 40\%) and affect compliance with the COVID-19 health protocol $(82 \%)$, where a person's age and education will relate to a person's knowledge because the experience and information that has been obtained from his education will be used as views or decision making in a problem, the results of the logistic regression test on the results of the partial test obtained a $p$ value $(0.000)$ so it can be explained that the knowledge variable will be the most influencing factor for compliance in carrying out the covid 19 protocol in 


\section{Journal Of Nursing Practice}

http://thejnp.org

the city of Kediri. The results of (Huang \& Zhao: 2010) research show that knowledge of the benefits of using masks affects protective behavior (using masks) in influenza pandemic situations. During a pandemic situation, the desire for isolation is determined by attitudes, perceptions of social norms and perceptions of behavioral control (Zhang, et al, 2020). Research by Wise, et al (2020) shows that the perception of the risk of contracting and the perception of the impact of COVID-19 (economy, health services) increases individual protective behavior (washing hands, maintaining social distance). Fear and anxiety about the COVID-19 virus play an important role in influencing protective behaviors, such as hand washing, social distancing (Harper et al., 2020). As the results of knowledge research at the upper secondary education level so as to provide sufficient knowledge about covid 19 so that someone will follow the covid 19 protocol.

The results of the anxiety variable research with a total sample of 114 obtained an average anxiety in the sufficient category (38\%), this is an indicator that with the emergence of a pandemic, people experience anxiety about the spread of the covid 19 virus, supported by demographic data, namely the average age of $31-35$ years and the average education of the respondents is at the high school level so that the anxiety that arises can still be managed well because it is also supported by sufficient knowledge from the respondents, but the logistic regression partial test does not have a direct effect but on the regression model jointly have an influence on compliance with the implementation of the covid 19 protocol. Anxiety in the community during a pandemic, sudden conditions make people unprepared to deal with it either physically or psychologically (Sabir \& Phil, 2016). Among the psychological conditions experienced by the community is a sense of anxiety when infected (Fitria, 2020). According to the American Psychological Association (APA), anxiety is an emotional state that arises when individuals are under stress, and is characterized by feelings of tension, thoughts that make individuals feel worried and accompanied by a physical response to a racing heart, rising blood pressure, and so on (Beaudreau \& O. 'Hara, 2009). Proper management of anxiety can provide the ability to control community compliance with the spread of COVID-19 and reduce the risk of spreading COVID-19.

The personality variable is dominated by respondents who have a tendency to have a melancholic personality (46\%) from a total of 114 respondents, where the melancholic personality characteristics are a thinker, detail, very careful in making decisions, sensitive and have empathy, this is according to the results of the regression test. logistics together with personality variables have an influence on compliance with the implementation of the covid 19 health protocol with a p value (0.000) and the variables of knowledge, personality and anxiety together affect health protocol compliance by $57.4 \%$ and the rest are influenced by other variables that have not been studied. And the most influential variable in the partial test is the knowledge variable with a $\mathrm{p}$ value $(0.000)$.

\section{CONCLUSSION}

The results of the research that have been conducted and analyzed show that the variables of knowledge, personality and anxiety affect health protocol compliance by $57.4 \%$ and the rest are influenced by other variables that have not been studied, and the variable that most influences the research is the knowledge variable in the partial test.

\section{CONFLICT OF INTERESTS}

The authors declare no conflicts of interest.

\section{FUNDING INFORMATION}

This research didn't receive any funding. 


\section{Journal Of Nursing Practice}

http://thejnp.org

ISSN: 2614-3488 (print); 2614-3496 (online)

Vol.5 No.1. October 2021. Page.189-195

\section{REFERENCES}

Izzaty. (2020). Kebijakan Pemerintah dalam Mengatasi Panic Buying Akibat COVID19. Info Singkat, 12(1), 20-30.

Howard, et.al, (2020). Face Mask Against COVID-19: An Evidence Review. PNAS 2020. DOI: $10.1073 /$ pnas.2014564118

Lee, J., Jing, J., Yi, T. P., Bose, R. J. C., Mccarthy, J. R., Tharmalingam, N., \& Madheswaran, T. (2020). Hand Sanitizers : A Review on Formulation Aspects , Adverse E ff ects, and Regulations. International Journal of Environmental Research and Public Health, 17, 2-17.

Hafeez, A., A. Shmmon.,A. S.Sameera., A.Mumtaz and M. A. Shruti. 2020. Review of COVID-19 (Coronavirus Disease-2019): Diagnosis, Treatments and Prevention. EJMO 2020; 4(2):116-125

World Health Organization (WHO). (2020). Coronavirus Disease COVID-19.27 September 2020, 10 am CEST.

Pratomo, Hadi. (2020). From Social Distancing to Physical Distancing: A Challenge for Evaluating Public Health Intervention against COVID-19. Jurnal Kesehatan Masyarakat Nasional (National Public Health Journal). 2020; Special Issue 1: 60-63 DOI: 10.21109/kesmas.v15i2.4010.

Tuwu, D. (2020) 'KEBIJAKAN PEMERINTAH DALAM PENANGANAN PANDEMI COVID-19', JournalPublicuho, 3(2), pp. 267-278. doi: 10.35817/jpu.v3i2.12535. Available at: http://ojs.uho.ac.id/index.php/PUBLICUHO/article/view/12535/pdf

Huang, Y. and Zhao, N. (2020) 'Generalized anxiety disorder, depressive symptoms and sleep quality during COVID-19 outbreak in China: a web-based cross-sectional survey', Esliver Psychiatry ResearchPsychiatry Research, 288(January), pp. 2-3.

Wise, et.al. (2020). Changes in risk perception and protective behavior during the first week of the COVID-19 pandemic in the United States. Royal Society Open Science. https://doi.org/10.1098/rsos.200742https://doi.org/10.1098/rsos.200742

Harper, et.al. (2020). Functional Fear Predicts Public Health Compliance in the COVID-19 Pandemic. International Journal of Mental Health and Addiction. https//:doi.org/10.1007/s11469-020-00281-5.

Zhang, X. et al. (2020) 'Perceived stress and sleep quality among the non-diseased general public in China during the 2019 coronavirus disease: a moderated mediation model', Sleep Medicine, (January). doi: 10.1016/j.sleep.2020.05.021.

Kiemute \& Julita. (2019). The Relationship between Personality Traits and Susceptibility to Social Influence. Computers in Human Behavior. https://www.researchgate.net/publication/330682687. DOI:10.1016/i.chb.2019.01.032

Van Berkel, et.al. (2020). Biomarkers for antimicrobial stewardship: a reappraisal in COVID-19 times?. Critical Care. https//:doi.org/10.1186/s13054-020-03291-w.

Sabir, A., \& Phil, M. (2016). Gambaran Umum persepsi masyarakat terhadap bencana di Indonesia. Jurnal Ilmu Ekonomi Dan Sosial, 5(3), 304-326.

Fitria, L. and Ifdil, I. (2020) 'Kecemasan remaja pada masa pandemi Covid -19', Jurnal EDUCATIO: Jurnal Pendidikan Indonesia, 6(1), p. 1. doi: 10.29210/120202592

Beaudreau, S. A., \& O'Hara, R. (2009). The association of anxiety and depressive symptoms with cognitive performance in community-dwelling older adults. Psychology and aging, 24(2), 507. 